\title{
Issues of Interpreting the Koran and Hadith
}

\section{Patrick Sookhdeo *}

\section{Orthodox Classical Interpretation}

Tafsir, the classical science of interpretation and explanation of the Koran, was consolidated in the tenth century. Tafsir accepted the Koran as the word of God revealed by divine inspiration (wahy) through Muhammad and divinely preserved. It is a miracle, inimitable and unique. As a divine theophany, each word is divine in and of itself, and therefore worthy of every human effort of study and contemplation. Tafsir proceeded through the scripture verse by verse and sometimes word by word. A symbolic and allegorical form of interpretation ( $t a$ 'wil) was also developed to explain the inner and concealed meanings of the text. The Koran is the criterion by which everything else is to be judged.

The Koran is accepted as the primary revealed source of Islam and of Islamic law (sharia). Muhammad was believed to have been given the responsibility of interpreting the Koran, so his words and acts-his sunnah, as found in the collected traditions (hadith)—became the second revelatory source, expounding the Koran.

The five traditional sources for commentary on the Koran are:

1. The Koran itself. The Koran was accepted as the very word of God. It is authoritative when it explains itself. The Koran is free of contradiction, and apparent inconsistencies in its message are inevitably resolved through closer study of the text.

2. Muhammad's explanations. Muhammad was sent to explain and clarify the Koran. The accounts of Muhammad's teaching recorded in the hadith collections contain much tafsir on the Koran.

3. The reports of the Sahaba (companions) of Muhammad, who also interpreted and taught the Koran. Where a Koranic explanation is absent, and there is no authentic tradition from Muhammad, a consensus of the companions may be used in interpreting a certain verse.

4. The reports of those who followed the companions, or the successors (tabi'un). These individuals were taught by the companions, so their insight is next in line.

5. Reason. A qualified scholar's personal reasoning, or ijtihad (deductive logic and personal evaluation of arguments), is the final method of understanding the Koran; it exists in conjunction with the other four.

In addition, there are five subjects of classical tafsir:

* Patrick Sookhdeo, Ph.D., D.D., FSyI, is the International Director of the Barnabas Fund and the Institute for the Study of Islam and Christianity, and is a Senior Visiting Fellow of the U.K. Defense Academy. 
1. The text: ambiguity, variant readings, defective texts, and apparent contradictions in the text of the Koran. It provided detailed background information and commentary on the text rather than analysis of its inner essence.

2. Legal rulings extracted from the text.

3. Determining which suras and verses were Meccan and which came from the Medinan period.

4. Determining the causes of revelation (asbab al-nuzul) of the various passages. This is important for analogical reasoning, as the contexts must be similar.

5. Specifying the abrogated and abrogating verses (nasikh and mansukh). The principle is that chronologically later verses abrogate earlier verses that contradict them. However, there is much discussion about which verses were abrogated, the number varying according to different scholars. Some limit abrogation to verses with legal injunctions only. Abrogation is valid not only when the Koran abrogates the Koran; according to some scholars, the Koran can also abrogate sunnah, sunnah can abrogate Koran, and sunnah can abrogate sunnah.

The variety of these discussions allow for a certain spectrum for divergent thought. For instance, the verse, "Let there be no compulsion in religion" (Q 2:256) elicits six different views in Tafsir al-Qurtubi (d. 1273): ${ }^{1}$

- This verse was abrogated by Muhammad himself when he forced the Arabs to adopt Islam. The supporters of abrogation see verse 9:73 ("Prophet! Strive hard [do jihad] against the unbelievers and the hypocrites") as the abrogating verse.

- The verse is not abrogated. It refers to the people of the book who are not forced to convert to Islam if they pay the jizya. However, idolaters are forced to convert.

- The verse's specific context concerns the exiled Jewish tribe of Banu Nadir. The tribe took with them adopted children of the Ansar. Those children who wanted to leave with the Jews were allowed to do so.

- Another context of revelation cites two sons of a man of the Ansar who became Christians. When the father complained about them to Muhammad, this verse was revealed, and no one was sent after them to bring them back. However, later the "no compulsion" verse was abrogated when Muhammad was ordered to fight the people of the book.

- The verse means that those who submitted through the sword should not be called "compelled" or "forced" (even though they were).

- Another context of revelation is that it concerns adult captives of the people of the book who were not compelled to become Muslims. Their children, however, were compelled. Magians too were compelled to adopt Islam.

Tafsir al-Qurtubi, Classical Commentary on the Holy Koran, translated by Aisha Bewley, vol. 1 (London: Dar al-Taqwa, 2003), 659-61. 
Important commentators and exegetes producing books of tafsir were al-Tabari (838-923), al-Maturidi (d. 983), al-Tha'labi (d. 1035), and al-Wahidi (1075). Later pre-modern authors of tafsir works were al-Zamakhshari (d. 1144), al-Razi (d. 1209), al-Baydawi (d. 1286), Ibn Kathir (d. 1373), al-Suyuti (d. 1505), al-Shawkani (d. 1839), and al-Alusi (d. 1854).

The Koran was interpreted using several methods. The first of these was also the most obvious: interpreting the Koran by the Koran. The most reliable commentary is contained in the Koran itself. The ways in which certain verses clarify others is regarded as the most significant form of commentary. The second method used of interpreting the Koran in tafsir is interpreting the Koran by the sunnah-by the Prophet's interpretations of the Koran. His comments on the Koran (as well as all he said or did) are recorded in the hadith collections. As mentioned above, the additional methods of interpreting the Koran involved using the sayings of Muhammad's knowledgeable companions (sahaba) and their successors (tabi'un), as recorded in the hadith, and using reason and ijtihad (tafsir bi'l ra'y).

The classical form of tafsir practiced by the exegetes mentioned above dealt with three main areas: linguistic issues, juristic issues, and theological issues. Linguistic issues involve questions of vocabulary and syntax, meanings of words and phrases, grammatical questions, issues of literal and non-literal meanings. These issues are most often addressed through interpreting the Koran by studying the Arabic language and classical poetry. As for juristic issues, the importance of law (sharia) meant that many Koranic scholars were preoccupied with legal issues, such as defining the commandment verses in the Koran. A distinction was made between the general and specific application of commandments. An important question was that of abrogation-the identification of abrogated and abrogating verses. A fourfold division of the meanings of the text was made into significative ('ibara), implicative (ishara), analogical (dalala), and assumptive (iqtida'). The final area of interpretation concerned theological issues. In these analyses, the problem of anthropomorphism was discussed, as was the sinlessness ( 'isma) of the prophets and the problem of free will versus predestination; reconciling the two extremes was a major preoccupation of the interpreters (mufassirun).

\section{Classifications of Hadith}

The various collections of hadith were crucial to the science of tafsir. While the hadith collections as a whole were regarded as in some way inspired, individual hadith were evaluated according to their reliability and classified as sound or unsound. The principal criteria for classification were the perfection (or otherwise) of the chain of transmission; the freedom of the text from defect; and the acceptance of the text by the $S a$ habah (in the case of Sunnis), the Tabi'un (their followers), and their disciples.

A number of classifications of hadith have been made. Four types of hadith can be identified according to reference to a particular authority: 
- Qudsi (Divine): a revelation from Allah (SWT); relayed with the words of the Prophet (PBUH). ${ }^{2}$

- Marfu' (elevated): a narration from the Prophet (PBUH)-e.g., I heard the Prophet (PBUH) saying...

- Mawquf (stopped): a narration from a companion-e.g., we were commanded to...

- Maqtu' (severed): a narration from a successor.

Six categories can be identified according to the links of Isnad-interrupted or uninterrupted:

- Musnad (supported): a hadith that is reported by a traditionalist, based on what he learned from his teacher at a time of life suitable for learning; similarly, in turn, for each teacher until the isnad reaches a well known companion, who in turn reports from the Prophet (PBUH).

- Mutassil (continuous): a hadith with an uninterrupted isnad which goes back only to a companion or successor.

- Mursal (hurried): if the link between the successor and the Prophet (PBUH) is missing - e.g. when a successor says, "The Prophet said..."

- Munqati' (broken): a hadith whose link anywhere before the successor-i.e., closer to the traditionalist recording the hadith—is missing.

- Mu'adal (perplexing): a hadith whose reporter omits two or more consecutive reporters in the isnad.

- Mu'allaq (hanging): a hadith whose reporter omits the whole isnad and quotes the Prophet (PBUH) directly-i.e., the link is missing at the beginning.

Five categories of hadith can be identified according to the number of reporters involved in each stage of Isnad:

- Mutawatir (consecutive): a hadith reported by such a large number of people that they cannot be expected to agree upon a lie.

- Ahad (isolated): a hadith narrated by people whose number does not reach that of the mutawatir. It is further classified into:

- Mashhur (famous): a hadith reported by more than two reporters.

- Aziz (rare, strong): at any stage in the isnad, only two reporters are found to narrate the hadith.

- Gharib (strange): at some stage of the Isnad, only one reporter is found relating it.

2 Note: Subhanahu Wa Ta'ala, abbreviated SWT, is a phrase of respect said after pronouncing the name of Allah. Muslims repeat the phrase "Peace be upon Him," abbreviated PBUH, after mentioning a Prophet’s name. 
Two categories of hadith can be identified according to the nature of the text and isnad:

- Munkar (denounced): a hadith reported by a weak narrator, and whose narration goes against another authentic hadith.

- Mudraj (interpolated): an addition by a reporter to the text of the hadith being narrated.

Four categories can be identified according to the reliability and memory of the reporters. This provides the final verdict on a hadith:

- Sahih (sound): Imam Al-Shafi'i states that if a hadith is not mutawatir, to be acceptable "each reporter should be trustworthy in his religion; he should be known to be truthful in his narrating, to understand what he narrates, to know how a different expression can alter the meaning, and to report the wording of the hadith verbatim, not only its meaning."

- Hasan (good): A hadith whose source is known and reporters are unambiguous.

- Da 'if (weak): a hadith that fails to reach the status of hasan. Usually, the weakness is one of discontinuity in the isnad, in which case the hadith could be (according to the nature of the discontinuity) munqati' (broken), mu'allaq (hanging), mu'dal (perplexing), or mursal (hurried); or it is one of the reporters having a less than reputable character, perhaps because he told lies, made excessive mistakes, opposed the narration of more reliable sources, was involved in innovation, or had an ambiguous character.

- Maudu' (fabricated or forged): is a hadith whose text goes against the established norms of the Prophet's sayings, or its reporters include a liar. Fabricated hadith are also recognized by external evidence related to a discrepancy found in the dates or times of a particular incident.

\section{Sharia and the Various Schools of Sharia}

In many ways, Islam is sharia: the Islamic way of life, the framework of dos and don'ts within which a Muslim leads his life. It is also a marker of identity separating Muslims from non-Muslims. While sharia refers to God's divine law as revealed in the sacred texts, fiqh is the human (scholarly) understanding of the law, its elaboration and interpretation. It connotes human scholarly activity and the literature it produces. Practitioners of fiqh, the fuqaha', try to discover and give expression to the sharia. ${ }^{3}$ Other legal and scholastic experts-'ulama, qadis, and muftis-also interpret and apply the law. Legal issues are dealt with by looking at the relevant Koran and hadith texts filtered through the long history of legal precedents and commentaries. The full implications of sharia were worked out during the first two centuries of Islam. Scholars and jurists created rules from the source texts through the device of "independent reasoning"

3 John Esposito, ed., The Oxford Encyclopedia of the Modern Islamic World, vol. 2 (New York: Oxford University Press, 1999), 450-62. 
( $r a^{\prime} y$ ) with the Sunnah serving as the interpretive framework to the Koran. $R a$ ' $y$ was soon rejected by most and replaced by logical deduction (qiyas) and scholarly consensus (ijma').

The various roots of Islamic law are called usul al-fiqh. Although sharia has evolved over time, the primary sources of sharia are the Koran and hadith. These are complemented when needed by a process of consensus (ijma') and analogical reasoning (qiyas).

Schools of Law. Four Sunni orthodox schools of law (madhahib, singular madhab), named after their founders, developed and had been codified by the end of the tenth century. The Shia developed a school of their own. The founders of the schools were:

- Abu Hanifa (700-67): the Hanafi madhab

- Malik ibn-Anas (715-95): the Maliki madhab

- Muhammad ibn-Idris al-Shafi'i (767-820): the Shafi'i madhab

- Ahmad ibn-Hanbal (780-855): the Hanbali madhab

- Ja'far al-Sadiq (700-765) (the sixth Shia Imam): the Ja'fari madhab, the Shia Twelver school.

Other marginal schools that have survived include the Shia Zaydi (Fiver) school, limited to Yemen, and the Shia Ismaili school. A small khariji-'Ibadi school has also survived in Oman. Most Muslims until recently were expected to belong to one of these schools, usually the one dominant in their region.

The founders of these various schools systematized the collections of hadith, dividing them by subjects and interpreting their meanings as well as applying them to legal issues. The schools differ in some of the criteria they use for reaching legal decisions and in some interpretations of Koranic regulations and details of prescribed rituals, but they accept each other as orthodox.

Sharia tries to describe in detail all possible human acts, dividing them into two general categories, permissible (halal) and prohibited (haram), and subdividing them into various degrees of good or evil such as obligatory, recommended, neutral, objectionable, or forbidden. Sharia regulates in detail all matters of devotional life, ritual purity, marriage and inheritance, criminal offenses, commerce, and the governing of the Islamic state. It also regulates relations with non-Muslims within the Muslim state as well as with enemies outside the state.

Islamic law is usually divided into two main parts. One deals with rituals ( 'ibadat), encompassing details on ritual purity, prayer, alms, fasting, pilgrimage, and sometimes jihad. The second main part of sharia addresses social relations (mu'amallat), covering criminal law; family law (marriage, divorce, inheritance); economic law (trade and commerce, contracts); and several other topics.

The category of criminal law is subdivided into laws regarding the obligations of humans towards each other (huquq al-insan) and laws governing human obligations toward God (huquq Allah), which include specific severe penalties for a number of crimes known as hudud (limits). Hudud punishments include the death penalty for apostasy and adultery as well as the amputation of limbs for theft. 
Sharia is interpreted and applied by Muslim legal and scholastic experts: ulama, fuqaha, qadis, and muftis. Legal issues are handled by these experts by looking at the relevant Koran and hadith texts filtered through the long history of legal precedents and commentaries.

Areas of Major Differences Among the Sunni Schools. There are several areas of significant difference between the main Sunni schools of sharia. The most important concerns the interpretation of the Koran, especially which verses are to be regarded as abrogated by later verses, and to what extent Koran and Sunnah abrogate each other. There are also differences on the meaning and implications of certain Koranic words.

A second area of difference is around the acceptance and interpretation of hadith. There is wide variety of opinion on the authenticity of various hadith, especially those reported by a single narrator, and on their interpretation.

A third major area of disagreement deals with the status accorded to rationalist doctrines in the various schools. There was much arguing between the schools on the validity and scope of application of the methods of consensus (ijma'), analogy (qiyas), reasoning $\left(r a^{\prime} y\right)$, and interpretation (ijtihad). There are additional areas of difference on subsidiary matters that are too detailed to address here.

\section{Characteristics of the Schools of Law}

The Hanafi school accepts the four roots of law (Koran, Sunnah, qiyas, and ijma'). It emphasizes the use of analogical deduction (qiyas), but also adds personal opinion $\left(r a^{\prime} y\right)$ and the principle of selecting from several options the legal decision that would most alleviate unnecessary hardship (istihsan). It is criticized by the other schools for emphasizing speculative opinion at the cost of hadith. It generally shows more respect for personal freedom and is more liberal than the other schools. It is also milder in its treatment of non-Muslims and war captives. The most important manuals of the Hanafi schools are the Zahir al-rawayah by Muhammad Hasan al-Shaybani, the Al-kafi ("The Concise") by al-Marwazi, and the Al-mabsut ("The Comprehensive") by Shams al-Din al-Sarakhsi. The Hedaya by Burhan al-Din 'Ali al-Marghinani (d. 1196) is another famous and authoritative textbook of Hanafi law. ${ }^{4}$

The Maliki school is more conservative in its emphasis on hadith, though it adds the criterion of public interest (maslaha) to the four accepted roots of law as a basis for its legal judgments. It also gives greater consideration to regional customs than do the other schools. The major manual of the Maliki school is the Al-mudawwana ("The Enactment”) by Asad al-Furat, which was later edited and arranged by Sahnun as $\mathrm{Al-mu-}$ dawwana al-kubra. Another important work is Khalil ibn-Isahq's Al-mukhtassar ("The Concise Summary of Law”).

4 Among the English translations of such manuals are: Al-Shafi'is Risala: Treatise on the Foundations of Islamic Jurisprudence, translated with an introduction, notes, and appendices by Majid Khadduri (Cambridge: The Islamic Texts Society, 1987); and Burhan al-Din 'Ali al-Marginani, The Hedaya: Commentary on the Islamic Laws, 2 volumes, translated by Charles Hamilton (New Delhi: Kitab Bhavan, reprinted 1985). 
The Shafi'i school emphasizes qiyas and ijma' and utilizes only the four roots of law in arriving at legal decisions. It rejects istihsan and maslaha as forms of interference with sharia. The school is more selective in its recognition of hadith, which it viewed as the only valid interpretation of the Koran. Al-Shafi'i propounded his teaching in the Risala ("The Message") and the seven-volume Kitab al-umm ("The Book of Essentials”). Important Shafi'i manuals are al-Nawawi's book Minhaj-at-Talibin, which is a standard work in Egypt, Malaysia, and Indonesia; and al-Suyuti's Al-ashbah wa'l-naza'ir.

The Hanbali school is the most literal and conservative of the schools, limiting the use of analogy (qiyas) and human reasoning, demanding that all legal decisions be based only on a literal interpretation of Koran and hadith and rejecting tools of adaptation such as istihsan and maslaha. Hanbalis preferred weak hadith to strong analogy. The works of the thirteenth-century scholar Taqi al-Din ibn-Taymiyya (d. 1327) are extensively used by Hanbalis.

The Twelver Shia school has its own distinctive collection of hadith. While it accepts Koran, sunnah, and ijma', it rejects qiyas and replaces it with reason ('aql) as the fourth source of law. The sunnah is expanded to include the practice and sayings of the twelve Shia Imams, accepted as infallible and inspired, having the status of divine revelation. The disappearance of the last Imam in 874 was seen as an occultation (ghayba.) He was believed to still exist in an invisible form, and will return in visible form at the end of time as the messianic mahdi who will usher in a period of universal peace and justice. In the meantime, the highest Shia jurists are his representatives, and ijma' means the consensus of these jurists, who also have the right of ongoing ijtihad. An important Shia manual is Al-kafi fi 'ilm al-din ("The Sufficient in the Knowledge of Religion”) by Muhammad ibn-Ta'qub al-Kulayni. Other important manuals were written by ibn-Babawayh (Man la-yahdurhu al-faqih) and al-Tusi (Tahdhib al-ahkam and al-istibsar). The most widely used manual among the Shia is Wasa'il al-shi'a by Hurr al'Amili (d. 1699). ${ }^{5}$

Disciples continued the founders' work, and over the centuries several widely accepted manuals were composed by famous masters that laid down all that was needed to be known about the law for all generations.

The development of the legal corpus in all schools depended on two principles: First is the requirement that any formulation of the law at any time must be justifiable by reference to revelation (Koran and hadith, i.e., Muhammad's sunnah). Second, participants in each tradition must remain loyal to their own tradition, taking into account the interpretive achievements of older masters. The law had to be justified by reference to the continuity and the established identity of the school. Scholars were to find their way back to the meaning of revelation only through tradition.

According to the traditional view, the canonical collections of Koran and hadith are equal in authority, although the Koran is superior in its nature and origins. In practice,

5 Andrew Rippin, Muslims: Their Religious Beliefs and Practices, vol. 1: The Formative Period (London: Routledge, 1990), 103-16; Abdulaziz Sachedina, "Shi'i Schools of Law," in The Oxford Encyclopedia of the Modern Islamic World, vol. 2, 463-64. 
however, the hadith collections dominated the hermeneutical process. The relationship between hadith and Koran was controversial. Some early jurists claimed that the sunnah might abrogate the Koran; others, that the sunnah passed judgment on the Koran; and yet others that it clarified and explained the Koran. All agreed with the statement that, "the Book is in greater need of the Sunnah than the Sunnah is of the Book" (alAwza'i, d. 774). ${ }^{6}$

Closing the Gates of Ijtihad and Taqlid. The founders of the five schools of Islamic law lived in the eighth century and the first half of the ninth century. From the tenth century onwards, scholars of the various school of law gradually reached a consensus that all essential questions of law had been comprehensively discussed and settled by the great founding scholars. By the end of the tenth century, efforts to find new interpretations of sharia came to an end. Later scholars were not deemed to have the necessary qualifications for independent reasoning, so all future activity had to be confined to the explanation, application, and interpretation of doctrines that had already been established. This "closing the door of ijtihad" opened the way for the practice of taqlid, the imitation of the great scholars and pious masters, which meant the unquestioning acceptance of the decisions of the established schools and authorities. ${ }^{7}$ Deviation from past jurists' opinions was disapproved of and considered sinful. Since that time, the sharia was seen as a set of static and unchanging norms, a comprehensive code from which there can be no variation. This development created a great reluctance among the majority of Sunni Muslims to indulge in ijtihad.

Mernissi sees the closing of the gates of ijtihad as part of the process of closing Islamic orthodoxy to the possibilities of freedom of thought under the "terror of the sword.” Political rulers (caliphs) and the religious establishment stifled debate, and intellectual opposition was repressed. Dissidence henceforth was expressed by violent rebellions against totalitarian leaders, killing them and replacing them with other totalitarian leaders, not by questioning and changing the political system. ${ }^{8}$

The Mu'tazila Interlude-Reason as Key. The Mu'tazila were a rationalist school of theology who were dominant in the Abbasid Empire in the ninth century. The Mu'tazila used dialectic, logic, and rational argument to develop their system. Mu'tazila thought led to a remarkable flourishing of Islamic science and culture, and to a relaxation in relations between Muslims and non-Muslims. Their main ideas were:

- Reason is a means of knowing God

- God's justice is God binding himself to act in accordance with his essential attributes

6 Esposito, ed., The Oxford Encyclopedia of the Modern Islamic World, vol. 2, 450.

7 J. Schacht, "Law and Justice," in The Cambridge History of Islam, Vol. 2B: Islamic Society and Civilization, P.M. Holt, Ann K.S. Lambton, and Bernard Lewis, eds. (Cambridge: Cambridge University Press, 1970), 563-64.

8 Fatima Mernissi, Islam and Democracy: Fear of the Modern World (New York: Perseus Books Group, 2002), 19-21, 34-35. 
- The Koran was created in time (did not exist eternally) and is open to interpretation by human reason

- The laws of nature, created by a reasonable God, are open to human investigation and are predictable, including a clear link between cause and effect

- Man is endowed with free will and is responsible for his actions.

The Ash'arites-Without Reason. However, opposing views to those of the Mu'tazila gained the upper hand and finally formed what we now think of as orthodox Sunni Islamic theology. The suppression of Mu'tazila thought led inexorably to closing the gates of ijtihad when all further development of sharia was banned. The victorious party was the Ash'arites, who taught that: ${ }^{9}$

- Man cannot know God or understand Him by his reason, but must simply obey and accept God's inscrutable and arbitrary omnipotence and will.

- Divine predestination overrules man's free will, and omnipotent power is God's main attribute.

- There is no link between cause and effect, as God in every moment creates all things anew according to his will. Creation is thus unpredictable, and there is no need to study natural laws or to seek causes of perceived effects. God is not accountable even to his own self and norms.

- The Koran is uncreated and has existed with God from eternity, and as such is more an object of worship and of unquestioned obedience than of reasoned interpretations.

The Ash'arite victory over the Mu'tazila profoundly influenced the development of Islam. First, a totalitarian view of God and of His will for the world developed. Believers were expected to practice strict obedience to sharia and its injunctions, including jihad and the treatment of non-Muslims, which encouraged totalitarian forms of government. Second, the Islamic ruler (whether Sunni caliph or Shia imam), as God's vice-regent and delegate on earth, acts as God does: his will is to be unquestioningly obeyed, he is accountable to no human agency, only to God. Third, a fatalistic Islamic world-view developed in which the will to power remains the only absolute, because that is what God is. The believer surrenders unconditionally to God's will, including its manifestation in a tyrannical political system. Finally, a system based on unreasonable pure will to power inevitably leads to violence to solve all problems. ${ }^{10}$ Will must be imposed by force, as reason has no place in the system.

9 Followers of Abul Hasan 'Ali ibn Isma'il al-Ash'ari (873-935), who repudiated his mu'tazila beliefs, became a Hanbali Sunni, and established the Ash'arite theology, which became the orthodox Sunni doctrine and has dominated Sunni Islam since the tenth century.

10 Fatima Mernissi refers to Nietzcshe's idea of the "will to power" as the most basic driving force in the universe and in human society, an idea picked up by Fascist and Nazi ideologues and borrowed from them by contemporary Islamists. 


\section{Classical Attitudes to and Interpretations of Jihad}

Classical scholarly interpretations of violence in Islamic theology are derived from the Koran, hadith, and sharia, as well as from the normative example of Muhammad and the experiences of violent conflicts in the early history of Islam. These factors provided the theoretical framework and paradigms within which jihad and the means it may employ are discussed, interpreted, legitimated, and implemented.

Most traditional Muslim scholars asserted that all "peaceful” verses in the Koran were abrogated by the so-called "Sword Verse" (Q 9:5), which commands Muslims to fight anyone who refuses to convert to Islam. It is clear from the hadith that Muhammad and the first Muslims understood the term jihad to include physical warfare and literal killing. In the hadith collections, especially those of Bukhari and Muslim, military jihad takes up almost all the space of the chapters devoted to jihad. Muhammad's military expeditions (ghazawat) are treated as forms of jihad, and Muhammad's companions are seen as being very much concerned with the offensive military activities of the Muslim community. ${ }^{11}$

Sharia clearly establishes jihad as one of the most basic religious duties. There is little difference between Sunni and Shia law concerning war. Linked to the concept of jihad is the division of the world into two domains: the House of Islam (Dar al-Islam) and the House of War (Dar al-Harb). Muslims are supposed to wage jihad to change the House of War (areas where non-Muslims are politically dominant) into the House of Islam, regions politically dominated by Muslims.

\section{Some Classical and Medieval Scholars on Jihad}

Shaybani (750-804), Siyar. Siyar is the branch of Islamic law concerned with international relations. The early Muslim jurists used to deal with siyar under the general heading of jihad. For Shaybani, the sword was a marker of the God-given Islamic government, given to deal with all possible forms of unbelief: polytheism, apostasy, People of the Book, and Muslim dissenters from Islamic orthodoxy:

Allah gave the Prophet Muhammad four swords [for fighting unbelievers]: the first against the polytheists, which Muhammad himself fought with; the second against apostates, which Caliph Abu Bakr fought with; the third against the People of the Book, which Caliph 'Umar fought with; the fourth against dissenters which Caliph 'Ali fought with. ${ }^{12}$

Abu'l-Hasan al-Mawardi (972-1058), Al-Ahkam al-Sultaniyya. Al-Mawardi stressed both earthly and heavenly rewards as legitimate motivation for jihad warriors. He defined the enemy in a jihad as those who refuse to convert to Islam. Jihad must be fought constantly, at least once a year.

11 Egdunas Racius, The Multiple Nature of The Islamic Da'wa, Doctoral Dissertation, The Faculty of Arts, University of Helsinki (Helsinki: Valopaino Oy, 2004), 51.

12 Shaybani, Kitab al-Siyar al-Kabir, I, 14-5, quoted in Majid Khadduri, War and Peace in the Law of Islam (Baltimore: Johns Hopkins University Press, 1955), 74. 
Ibn Rushd (Averroes, d. 1198), Bidayat al-Mujtahid wa Nihayat al-Muqtasid. ${ }^{13}$ According to Ibn Rushd, there is a scholarly consensus that all polytheists (mushrikun) are to be fought and that it is permissible to enslave them-men, women, and children. Only monks are exempt from being enslaved, revealing that People of the Book are included in his definition of polytheists. There is also a consensus that it is permissible in war to kill all adult male polytheist fighters, but once taken as prisoners there is some argument as to whether they may be executed and in what circumstances. ${ }^{14}$

Ibn Taymiyya (1263-1328). According to Ibn Taymiyya, the aim of jihad is to make Islam dominant in the world, and all those who oppose this purpose must be fought: "Since lawful warfare is essentially jihad, and since its aim is that the religion is God's entirely and God's word is uppermost, therefore according to all Muslims, those who stand in the way of this aim must be fought." ${ }^{, 5}$ God has provided both Koran and sword to win the world to his religion, Islam: "There are two things which can establish and sustain religion: the Koran and the sword.”16

He advocated a permanent struggle between Islam and non-Muslims. Wherever Muslims are a weak minority, they must endeavor by all possible means to become powerful and dominate the non-Muslims. ${ }^{17}$ Ibn Taymiyya exalted military jihad as the best religious act a man can perform, better than pilgrimage, prayer, or fasting. Jihad implies "all kinds of worship, both in its inner and outer forms. More than any other act it implies love and devotion for God."18

Ibn Naqib al-Misri (d.1368), 'Umdat al-Salik ("Reliance of the Traveler”). This is an important Shafi'i text. According to Ibn-Naqib al-Misri, an Egyptian Hanafi jurist, jihad is fought against Jews, Christians, Zoroastrians, and all other people-basically against all non-Muslims: "The caliph makes war upon Jews, Christians, and Zoroastrians until they become Muslims or else pay the non-Muslim poll tax.... The caliph fights all other peoples until they become Muslim." ${ }^{19}$

Ibn Khaldun (1332-1406), The Muqaddima. The North African philosopher-historian Ibn Khaldun defined jihad as "a religious duty, because of the universalism of the [Muslim] mission and [the obligation to] convert everybody to Islam either by persuasion or force."20

13 Ibn Rushd, The Distinguished Jurist's Primer (Bidayat al-Mujtahid), translated by Imran Ahsan Khan Nyazee, vol. 1 (Reading: Garnet Publishing, 1994), 454-87.

14

15

16 yah (Delhi: Adam Publishers, 1982), 37.

17

18

19

20 Ibid., 455-57. (Princeton, NJ: Markus Wiener, 1996), 49. MD: Amana Publications, 1997), 602-3.

Ibn Taymiyya, translated in Rudolph Peters, Jihad in Classical and Modern Islam: A Reader

Ibn Taymiyya, al-Siyasa, quoted in Qamaruddin Khan, The Political Thought of Ibn Taymi-

Ibn Taymiyya, translated in Peters, Jihad in Classical and Modern Islam, 47-48.

Ahmad Ibn Naqib al-Misri, Reliance of the Traveller: A Classic Manual of Sacred Islamic Law ('Umdat al-Salik), edited and translated by Nuh Ha Mim Keller, rev. ed. (Beltsville,

Ibn Khaldun, The Muqaddimah: An Introduction to History, trans. Franz Rosenthal, vol. 1 (London: Routledge \& Kegan Paul, 1958), 473. 
Sheikh Ahmad Sirhindi (1564-1624). Sirhindi argued forcibly against any accommodation with Hinduism, as Hindus were kafirs. He sought to revive the earlier jihadi spirit of the Islamic state, arguing that "Shariat can be fostered through the sword": ${ }^{21}$

Kufr and Islam are opposed to each other. The progress of one is possible only at the expense of the other and co-existence between these two contradictory faiths is unthinkable. The honor of Islam lies in insulting kufr and kafirs. One who respects kafirs, dishonors the Muslims. ... They should be kept at an arms' length like dogs.... The real purpose in levying jizya on them [the non-Muslims] is to humiliate them to such an extent that, on account of fear of jizya, they may not be able to dress well and to live in grandeur. They should constantly remain terrified and trembling. It is intended to hold them under contempt and to uphold the honor and might of Islam. ${ }^{22}$

Shah Wali Allah of Delhi (1702-62). According to Shah Wali, jihad-fighting in God's way-is the perfect implementation of sharia. Leaders of non-Muslim communities who refuse to accept Islam must be killed, and their followers forcibly converted to Islam. ${ }^{23}$

It has become clear in my mind that the kingdom of heaven has predestined that kafirs should be reduced to a state of humiliation and treated with utter contempt. Should that repository of majesty and dauntless courage [Nizam al-Maluk] gird his loins and direct his attention to such a task he can conquer the world. Thus the faith will become more popular and his own power strengthened; a little effort will be profoundly rewarded. ... You should therefore not be negligent in fighting jihad. ... Oh Kings! Mala a'la urges you to draw swords and not put them back in their sheaths again until Allah has separated Muslims from the polytheists and the rebellious kafirs and the sinners are made absolutely feeble and helpless. ... We beseech you [Durrani] in the name of the Prophet to fight a jihad against the infidels of this region. This would entitle you to great rewards before God the Most High and your name would be included in the list of those who fought jihad for His sake. As far as worldly gains are concerned, incalculable booty would fall into the hands of the Islamic ghazis and the Muslims would be liberated from their bonds. ... Jihad should be their first priority, thereby ensuring the security of every Muslim. ${ }^{24}$

21 Sayyid Athar Abbas Rizvi, Muslim Revivalist Movements in Northern India in the Sixteenth and Seventeenth Centuries (New Delhi: Agra University Press, 1965), 247.

${ }^{22}$ Ibid., 248-49.

23 Sayyid Athar Abbas Rizvi, Shah Wali-Allah and His Times (Canberra: Ma'rifat Publishing House, 1980), 294-96, 299, 301, 305, quoted in Andrew G. Bostom, ed., The Legacy of Jihad: Islamic Holy War and the Fate of Non-Muslims (New York: Prometheus Books, 2005), 202-3.

${ }^{24}$ Sayyid Athar Abbas Rizvi, Shah Wali-Allah and His Times, 294-296, 299, 301, 305, quoted in Bostom, ed., The Legacy of Jihad: Islamic Holy War and the Fate of Non-Muslims, 2023. 


\section{Modern Interpretation}

Since the nineteenth century, efforts have been made to reform sharia by returning to the original sources and by reopening the gates of ijtihad. These efforts can be divided between those that would pursue modernization and liberalization to keep Islam in step with other contemporary civilizations, and those that would create a stricter, more puritanical faith completely unblemished by any outside influence.

Modern interpretation or the Koran and hadith is based on three interrelated principles: ${ }^{25}$

- Use of scientific reason and methodology to interpret the Koran, or use of the Koran itself and rejection of extraneous material found in hadith and earlier commentaries

- Divesting the Koran of presumed legendary traits, fantastic stories, magic, fables, and superstitions, and focusing instead on symbolic interpretation

- Rationalizing Islamic doctrine by basing it solely or mainly on the Koran.

Some of the key characteristics of modern interpretation include:

- An emphasis on the spiritual content of the Koran

- Diminished interest in grammar, rhetoric, and theology

- Greater emphasis on modern problems in economic, social, moral, and political spheres that affect Muslims

- Use of tafsir as a vehicle to advance ideas in these spheres, for reform and revival

- The assumption that Koranic suras are unities with significant order and coherence

- Emphasis on efforts to demonstrate the harmony between science and Islam

- Rejection of taqlid and the reopening of the gates of ijtihad in order to achieve their goals. Ijtihad is seen as the God-given method for social and political change, and is held to be an essential element in Islamic thought to ensure Islam's vitality. The "closing of the gates" was a serious mistake, which led to the decay of Muslim civilization. ${ }^{26}$

Many Muslim reformers have seen the return to the sources of Islam (Koran and sunnah), the downgrading of the authority of the four legal schools (madhahib), and the discarding of later traditions as the "golden key" that would cure Muslim societies of their backward state and political weakness vis-à-vis the West. This approach enabled scholars to select and mix from the different compendiums at will and borrow the best elements from Western cultures, setting up the good of the community (maslaha)

25 Andrew Rippin, Muslims: Their Religious Beliefs and Practices, vol. 2: The Contemporary Period (London: Routledge, 1993), 86-97.

${ }^{26}$ Muqtedar Khan, “Who are the 'moderate' Muslims?” Islam for Today website. Available at: http://islamfortoday.com/khan08.htm 
as the ultimate value and criterion. The reformers also rejected common law ('adat, 'urf) and popular Sufi practices. ${ }^{27}$ Most reformers also stressed the importance of reason and differentiated between a core set of sharia that was unchangeable and eternal (either the part that deals with duties to God, 'ibadat, or a core of universal values), and the larger part dealing with social relations in society, which was open to change and to adaptations to new contexts. ${ }^{28}$ Many also rejected the doctrine of abrogation, replacing it by harmonizing the various contradictory Koranic passages in the light of the text's eternal universal core values.

Koranic commentaries, tafsir, have become a vehicle for the spread of new ideas in the Muslim world. A variety of concepts are made relevant to contemporary Muslims by trying to base them in the Koranic text. A wide variety of views on what constitutes true Islam has developed, including modernist, modernist with a universalist emphasis, radical Islamist with literary and scientific emphases, as well as neo-traditionalist with a philological emphasis. All compete for dominance in the wider Muslim world of today. Two main issues arise, however, in all of these views: the miraculous nature of the Koran and its rationality; and the difference between moral and legal obligations. ${ }^{29}$

\section{Early Reform}

Sayyid Ahmed Khan in India (1817-98). ${ }^{30}$ Sayyid Ahmad Khan was the first modern reformer to make a substantial impact on the Muslim world. He founded the Muhammadan Anglo-Oriental College at Aligarh, India, with the aim of producing an educated elite of Muslims able to compete successfully with Hindus for jobs in the colonial Indian administration. He believed that the only hope for Islam in the colonial world lay in modernizing Muslim institutions. Khan wrote the first modernist commentary on the Koran, the Tafsir al-Koran. The following points provide an overview of Khan's approach:

- The Koran, properly understood and reinterpreted by reason, would supply a guide to Islam's accommodation to Western influence and the modern world, and reconcile the contradictions between traditional Islam and modern science. ${ }^{31}$

- Sunnah should be modified by weakening the hold of ijma' and renewing the right of ijtihad.

- A fundamental distinction must be made between details of revelation ( $f u r u$ ') and the general principles underlying them ('usul).

27 Olivier Roy, The Failure of Political Islam, trans. Carol Volk (Cambridge, MA: Harvard University Press, 1994), 32-33.

28 John L. Esposito, “Contemporary Islam: Reformation or Revolution?” in The Oxford History of Islam, Esposito, ed. (New York: Oxford University Press, 1999), 683-84.

29 Rippin, Muslims: Their Religious Beliefs and Practices, vol. 2, 97.

30 Akbar Ahmed, Living Islam (London: BBC Books, 1993), 118, 119; Malise Ruthven, Islam in the World (Oxford: Oxford University Press, 1984), 300-2.

31 Rippin, Muslims: Their Religious Beliefs and Practices, vol. 2, 86-87. 
- Sharia must be reinterpreted for modern contexts. Traditional sharia reflects the ideas and practices of the first generation of Muslims.

- All laws are subject to change according to circumstances; only the ibadat (regulations governing worship and religious rituals) were perfect and immutable.

In addition to these key elements of his thought, Khan challenged orthodox interpretation on several additional points. He questioned the sunnah as the infallible source of law and criticized the methodology of the early hadith collectors, including Bukhari and Muslim, in terms similar to those put forth by the Western scholars, Goldziher and Schacht. Khan also advocated the free choice of rulings from all schools of law, instead of requiring adherence to a single school. Finally, he tried to harmonize Islamic rules with Western norms, arguing that Islam condemned slavery and that jihad was only defensive in nature.

Muhammad 'Abduh (1849-1905) and Egyptian Reform. 'Abduh, the grand mufti of Egypt, wrote a commentary, Tafsir al-Manar, which is marked by a rationalist spirit and provides moral direction for Muslims in the modern world. He urged a return to the sources of Koran and sunnah as the ultimate authority, thus denigrating the importance of the traditional legal schools. He used modern knowledge and human reason to interpret the Koran, saying that everything needed is found in the Koran and arguing that the aim of the text is to provide moral principles applicable to all times. ${ }^{32}$ In addition, he rejected rigid scholasticism and taqlid, and distinguished between the unchanging core of Islam and its external manifestations, which were open to change. He asserted that there was no conflict between Islam and modernity. Revelation and reason were not contradictory, but complemented each other as the two sources of Islam.

'Abduh used Mu'tazili rationalism and revived the earlier genre of reason-based exegesis (tafsir bi'l-ra'y), which had lain dormant for centuries. He hoped to reform Islam and sharia by discovering the real intent of its unchanging fundamental principles, as well as by selectively appropriating aspects of Western culture and practice that are not contrary to Islam. He recognized that regulations of worship ('ibadat) were unchangeable, but asserted that precepts on social affairs (mu'ammalat) were open to re-interpretation and change, with the aim of promoting the welfare of society.

He followed the Maliki principle of seeking to serve maslaha (public interest) in his legal rulings (fatwas), allowing the law to be changed according to modern requirements. 'Abduh also used the principle of talfiq (piecing together), whereby rulings were developed by systematically comparing the views of the four madhabs and selecting the ones most consonant with maslaha and with the universal principles of Islam. ${ }^{33}$ He believed that Islam should attempt to control change via decisions that would be based on Islamic criteria for selecting what is good for modern life. He fought against traditional tafsir, arguing for the need to make Koranic commentary accessible

32 Rippin, Muslims: Their Religious Beliefs and Practices, vol. 2, 88-89.

33 John J. Donohue and John L. Esposito, eds., Islam in Transition (New York: Oxford University Press, 1982), 9; Esposito, Islam: The Straight Path (New York: Oxford University Press, 1990), 132-34. 
to all Muslims. This new commentary must be relevant to modern needs, rejecting theological speculations and detailed grammatical discussions.

Fazlur Rahman (1919-88). Rahman directed the Islamic Research Institute in Pakistan until conservative elements pressured him to leave. His book, Major Themes of the Koran, uses his method of interpreting the text not literally but by looking for the moral intention behind it. In order to interpret the Koran meaningfully for modern times, he believed a double movement of thought is needed. First, scholars must be able to think back and compare present situations to Koranic times. This requires an understanding the meaning of the Koran as a whole, as well as its specific tenets that are responses to the specific contextual situation of its time. Second, scholars must be able to project from Koranic times to the present, generalizing specific answers as universal and applying them to present realities and contexts.

Rahman also differentiated between legal and moral regulations, saying that legal rulings are binding primarily in their moral sense, not in their literal wording. In addition, he believed that much of classical Islamic commentary and law was wrong because the jurists had ignored the moral imperative behind the text, viewing the text as containing unchangeable, literal legal enactments. Muslims have failed to understand the true meaning of the Koran because of the traditional methods that have been used in interpreting it, which led to the creation of the traditional sciences of the Koran and the legal framework of sharia, and the rejection of Islamic philosophy. Buried under the debris of grammar and rhetoric and the many commentaries on commentaries on Koran and hadith written by scholars of the past, the Koran lost its vibrancy and revolutionary import. Finally, he believed that Muslims could free themselves from the burden of the past by studying history critically and differentiating the essentials of the faith from all unnecessary additions. ${ }^{34}$

\section{Radical Reform: Mahmud Muhammad Taha in Sudan ${ }^{35}$}

The Sudanese scholar and religious leader Dr. Mahmud Muhammad Taha made a sharp distinction between the Meccan and the Medinan parts of the Koran, which carried different messages. He called for a totally new revision of sharia, and was executed as an apostate by the Nimeiri regime in Sudan in 1985. The main points of his thought are as follows:

- The Meccan revelation constitutes the essential, universal, and unchangeable principles of Islam, valid for all times.

- The Medinan revelation consisted of temporal rules suitable for the context of tribal Arabia in the seventh century. The Medinan passages were concessions to the backward and barbaric society of the time, and are irrelevant to the modern age.

34 Rippin, Muslims: Their Religious Beliefs and Practices, vol. 2, 109-11.

35 Gerhard Lichtenthäler, "Muslim, Mystic and Martyr: The Vision of Mahmud Muhammad Taha and the Republican Brothers in the Sudan: Towards an Islamic Reformation?” Islam et Societes au Sud du Sahara 9 (November 1995). 
- The Meccan revelation mandates religious freedom and equality between the sexes.

- Instead of returning to the original sunnah as well as to the Medinan passages, Muslims should pursue an endless evolution of sharia based solely on the universalist principles of the Meccan passages.

- Ijtihad should be based on rational thought and on mystical reflection aimed at understanding the metaphorical meanings of the Koran.

\section{Shia Calls for Reform}

Ali Shariati in Iran - Islamic Liberation Theology. Ali Shariati, the main ideologue of the Iranian Islamic revolution, developed a revolutionary Islamic ideology very different from Khomeini's traditional brand of theology. ${ }^{36}$ It was rooted in Western existentialism, dialectical Marxism, and anti-imperialism as well as in reinterpreted versions of Shiite Islam and Sufism. ${ }^{37}$ Shariati's thought shared many similarities with Christian Liberation Theology. He maintained that Islam is a revolutionary ideology because, from its inception, it sided with the oppressed. Muhammad had fought for social equality and surrounded himself with the deprived members of society. ${ }^{38}$ Shariati's ideology's key goals were to:

- Integrate modernity with Islam, reinterpreting Islam in modern sociological categories, while recasting Western political and sociological thought into a Muslim idiom.

- Transform Islam into a mass revolutionary movement. Shariati posited an imagined early anti-clerical and revolutionary Alawi Shia Islam that needed to be revived in order to emancipate the masses from oppression. According to this view, Muhammad and his companions were social reformers and revolutionaries. ${ }^{39}$

36 Suroosh Irfani, Revolutionary Islam In Iran (London: Zed Books, 1983), 116; Dabashi, “Ali Shariati’s Islam: Revolutionary Uses of Faith in a Post-Traditional Society,” Islamic Quarterly 27: 4 (1983): 203.

37 The Sufi strand in Shariati's thinking, including the impact of Jalal al-Din Rumi's “Masnavi," and Massignon's influence has been comparatively ignored by scholars, except for Ali Rahnema. In Pioneers of Islamic Revival, Rahnema states that, in Massignon's company, Shariati underwent a significant inner transformation. See Ali Rahnema, ed. Pioneers of Islamic Revival (London: Zed Books, 1994), 212, 220-21. This is further elaborated in Rahenma's An Islamic Utopian, where Rahnema states that Shariati, during his student days in Paris, was a research assistant to Massignon, and that Massignon became his spiritual master (pir). See Ali Rahenma, An Islamic Utopian: A Political Biography of Ali Shariati (London: I.B. Tauris, 1998), 120-23.

38 Ali Shariati, Martyrdom: Arise and Bear Witness, trans. Ali Ghassemy (Tehran: Ministry of Islamic Guidance, 1981), 20-21.

39 Ali Shariati, What Is To Be Done: The Enlightened Thinkers and an Islamic Renaissance (Houston: IRIS, 1986), 54. 
- Encourage the understanding that Koranic texts have many possible meanings, some hidden, and some open to multiple interpretations.

- Recognize Islam's bias towards the poor based on its founding liberating document, the Koran, which states that "God is the God of the oppressed" and the "God of the deprived.",40

- Understand contemporary's Islam developmental stage as similar to that of Europe at the time of the Protestant Reformation. ${ }^{41}$ The Reformation created a paradigm shift in society, releasing vast energies that generated Europe's leap forward into modernity. Islamic societies need a similar religious reformation that will unleash similar energies, lead to "a great leap forward," and move them from passive fatalism and blind obedience to learned men and clerics (the ulama) to become a dynamic force in the world, reaching the level of Western societies in one generation. ${ }^{42}$

- Undermine the ulama's monopoly over religion by accusing them of creating a false Islam. They were reactionaries who limited themselves to "philosophy, theology, jurisprudence, conjugation, and syntax," diverting people's attention from the real causes of their misery and ignoring the core truths of Islam. ${ }^{43}$

'Abdul Karim Sorush. A leading Iranian intellectual and philosopher, he further developed Shariati's ideas by adopting a view of Islam influenced by Western phenomenology and liberal Christian theology. One of his key teachings was that Islam bears many interpretations that vary with time and context. Imposing a fixed interpretation makes Islam rigid, superficial, and one-dimensional. Related to this point was his contention that God and his revelation are eternal and immutable, but religion is relative, because it exists in the realm of human understanding and language, where everything is relative. Sacred texts do not change, but their interpretations should always be in flux.

Sorush distinguished between fundamentals (usul) and branches (furu') of Islam. He also held that traditional fiqh cannot provide solutions for Muslims in the modern world, and that Islam needs a new, dynamic and forward-looking fiqh, which will be able to address the problems of Muslims in modern contexts. The final distinguishing point of Sorush's thought is that the will of the majority must shape the ideal Islamic state, not the dictates of the ulama, and that there is no contradiction between Islam and the freedoms inherent in democracy. ${ }^{44}$

40

41

Ibid., 1; Shariati, Martyrdom: Arise and Bear Witness, 78.

Ali Shariati, On the Sociology of Islam, trans. H. Algar (Berkeley, CA: Mizan Press, 1979), 58; Shariati, What Is To Be Done, 18; Shariati, Man and Islam, trans. Marjani (Houston: FILINC, 1981), 103, 104.

Shariati, What Is To Be Done, 24, 25; Shariati, Man and Islam, 105.

Shariati, On the Sociology of Islam, 109, 116-18; Shariati, Man and Islam, 23; Shariati, Fatima is Fatima (Tehran: Tahrike Tarsile Quran, 1980), 6-7.

Ruthven, Islam in the World, 373-74; Ali R. Abootalebi, "Islam, Islamists, and Democracy," Middle East Review of International Affairs 3:1 (March 1999). 


\section{Contemporary Feminine Reform: The Malaysian Sisters in Islam}

"Sisters in Islam" is a group of Muslim professional women concerned by the injustice women suffer in states where sharia has been implemented. They claim the right to participate in the contemporary processes of reclaiming, redefining, and implementing Islam. They reject dogmatic, extremist, and intolerant forms of Islam that cannot provide solutions to the complexities of the modern world. Their tenets include:

- Belief that the Koranic universal principles of equality, justice, and freedom (including equal rights for women) override opposing rules set forth in traditional sharia. $^{45}$

- An opposition to continuing attempts to impose hudud punishments (such as the death sentence for apostasy) and traditional sharia law at both federal and state levels in Malaysia.

- Interpretation of the Koran on the reformist principles of stressing the eternal validity of a few fundamental universalist principles that override other verses or hadith that seem to contradict them, as well as on harmonization, which gives equal weight to all verses and denies the validity of the abrogation principle.

- An opposition to Islamism, which promotes an intolerant vision of an Islamic state-a dictatorial, theocratic, and inherently inequitable system that allocates different rights to men than to women, and to Muslims than to non-Muslims. ${ }^{46}$

- Calls for the doors of ijtihad to be reopened.

- Recognition of the Koran as divine revelation, but interpretation of the Koran as a human effort that leads to diverse opinions. This diversity is a positive value that enables Islam to survive in a variety of cultures and societies while preserving its universalist message.

- A conviction that the interpretation of the source texts and ijtihad must not be left in the hands of an exclusive elite group like the 'ulama, who isolate the text both from its socio-historical context and from contemporary contexts. Sisters in Islam promote lay interpretations of the Muslim scriptures, arguing that all Muslims should be involved in the discourse of what kind of Islam is right at this time. Only enlightened interpretations of Koran and hadith will provide solutions to the problems Muslims face today.

\section{Islamists}

Abu'l A'la Mawdudi (1903-79). Mawdudi was influenced by al-Banna, and founded the Jama'at-i Islami in 1941 as an elitist vanguard organization aimed at establishing an Islamic order. In his Tafhim al-Koran he hoped to present a unitary "Islamic mes-

45 “About SIS: Mission,” Sisters in Islam homepage, at: www.muslimtents.com/sistersinislam/ about/content1.htm.

46

“Islam, Apostasy and PAS,” Resources @Sisters in Islam (22 July 1999). Available at: www.muslimtents.com/sistersinnislam/resources/1apostat.htm 
sage” for $d a$ 'wa purposes and to foster the complete transformation of the individual, society, and politics in line with Islamic ideology. He believed a number of factors would bring about this transformation. First, Islam, as a total ideological system, must come to dominate all areas of public life (political, societal, economic), as well as personal matters and private worship. In line with the view that Islam should control all affairs of political life is Mawdudi's teaching that the Koran is a revolutionary manifesto and a manual for Islamist activists - it is an implicitly political work.

In implementing the political and social order called for in the Koran, a highly motivated vanguard of enlightened Muslims would act as catalysts of the Islamic revolution. Once this vanguard had succeeded in creating a truly Islamic state, this stateruled by sharia - will solve all problems that Muslims face worldwide. Mawdudi taught that jihad is the way to alter the ideology and social order. While embracing the classic military understanding of Islam, he also considered jihad to cover non-violent means such as campaigning for change by speech and writing. ${ }^{47}$

Sayyid Qutb (1907-66). Sayyid Qutb was the primary ideologue of the Muslim Brotherhood in Egypt during the rule of President Nasser (1954-70) and is viewed as the godfather of Islamist radicalism. Qutb wrote a commentary called Fi Zilal al-Koran ("In the Shade of the Koran"), which is extremely popular in the contemporary Muslim world. His axiom was that Islam is a perfect system that integrates freedom, equality, and social justice and is in accord with the cosmic order and the laws of nature. He embeds his radical interpretation of Islam in the Koranic text, using Koranic stories and concepts as paradigms applicable to the modern world. Among his primary concepts are:

- Islam is a comprehensive ideology that must regulate all aspects of life by implementing sharia as the legal system of the state.

- Reason and public welfare are important principles of interpretation, but only within the framework of Islamic rules.

- The paganism of Muhammad's time (jahiliyya) is replicated in the neo-paganism of the modern secular world, both Western and Muslim. Pharaoh is the prototype of the evil dictators and tyrants of today who want to destroy Islam; Moses is the prototype of the true Muslim leader who fights to liberate his people by bringing them under the yoke of sharia - true worship of God.

- Strong opposition to traditional commentaries that were atomistic in their approach to the Koran. His approach is holistic, seeing the Koran as a unity that mirrors and demands the unity of the Muslim umma. ${ }^{48}$

- Promotion of the Khariji doctrine of takfir, the process of judging Muslimswhether individuals, regimes, societies, or states - to be apostates or infidels if

47 Sayyid Abu'l A’la Mawdudi, Jihad fi Sabilillah [Jihad in Islam], trans. K. Ahmad (Birmingham, U.K.: Islamic Mission Dawah Centre, 1997), 13-15.

48 Rippin, Muslims: Their Religious Beliefs and Practices, vol. 2, 91-93. 
they do not wholly conform to the sharia. They must be fought, killed, and replaced.

- A transformation in the understanding of the hijra (emigration), from the traditional description of Muhammad's migration to Medina to an interpretation of the hijra as a distinct stage in the development of the contemporary ideal Islamic state. Hijra should be the response of true Muslims to the state of ignorance and immorality prevalent in society.

- Employing a term previously reserved for the paganism of pre-Islamic Arabia, he called this ignorance and immorality jahiliyya. ${ }^{49}$

- Identification of all jahili societies as the enemy, thus supplying a specific focus for revolutionary action. Jahiliyya is always evil in whatever form it manifests itself, as it is always seeking to crush true Islam.

- Jihad by force must be used to annihilate jahili regimes and replace them with true Muslim ones. ${ }^{50}$ He emphasized the qital (fighting) aspect of jihad, ${ }^{51}$ and strongly rejected any solely defensive interpretation. ${ }^{52}$ He saw jihad as a method for actively seeking to free all peoples on earth from non-Islamic authority. ${ }^{53}$

Muhammad Ibn 'Abd al-Wahhab (1703-92). Al-Wahhab founded a puritanical and militant reform movement based on the Hanbali madhab and on ibn-Taymiyya's teachings. He linked his movement to the House of Saud, and this strictly puritanical Wahhabism remains the predominant Islamic movement within Saudi Arabia today. He considered Muslim society at the time to have reverted to paganism (jahiliyya), and thus revived the Khariji practice of takfir, in which he condemned all Muslims he disagreed with as apostates in order to justify fighting jihad against them. He rejected all innovations that occurred after the third Islamic century, and urged a return to the Koran and sunnah in a pious interpretative attempt (ijtihad) to understand and implement their fundamentals. He condemned Sufis and Shia as apostates for adopting supersti-

49 Yvonne Y. Haddad, “Sayyid Qutb: Ideologue of Islamic Revival” in Voices of Resurgent Islam, John Esposito, ed. (New York: Oxford University Press, 1983), 85-87; Ronald Nettler, “A Modern Islamic Confession of Faith and Conception of Religion: Sayyid Qutb’s Introduction to tafsir, Fi Zilal al-Quran,” British Journal of Middle Eastern Studies 21:1 (1994): 102-4.

50 Sayyid Qutb, The Islamic Concept and its Characteristic (Indianapolis: American Trust Publication, 1991), 12.

51 Yvonne Y. Haddad, “The Quranic Justification for an Islamic Revolution: The View of Sayyid Qutb,” Middle East Journal 37:1 (Winter 1983): 17-18.

52 Nettler, "A Modern Islamic Confession of Faith,” 98-102; S. M. Solihin, Studies on Sayyid Qutb's Fi Zilal al-Quran, unpublished thesis, Department of Theology, University of Birmingham (U.K.) (1993), 284.

53 Sayyid Qutb, Islam and Peace (Cairo: Dar al-Shuruq, 1988), 80-85; Sayyid Qutb, Fi Zilal al-Quran, vol. 3 (Beirut: Dar al-Shuruq, 1987), 1433-35; Sayyid Qutb, Milestones (Lahore: Qazi Publications, no date), 88-89. See also Sayyid Qutb, Milestones (Ma'alem Fil Tariq) (Indianapolis: American Trust Publications, 1990). 
tious innovations, and urged the renewal of abandoned original model of Islam-that only principles of the Koran and sunnah were ultimately binding, and that decisions made by later medieval scholars lacked authority.

\section{Salafis}

The Salafis view the first three generations of Muslims (Muhammad's companions, and the two succeeding generations after them-the pious forbears, al-salaf al-salih) as the perfect examples of how Islam should be practiced. This principle is derived from the hadith of Muhammad: "The best of people is my generation, then those who come after them, then those who come after them"-i.e. the first three generations of Muslims (Bukhari 3:48:819 and 820; Muslim 31:6150 and 6151).

Islam was perfect and complete in the days of Muhammad and his companions, but a great deal of undesirable "innovation" (bid'a) was added to Islam afterwards. Salafism seeks to revive the original practice of Islam. Salafis are preoccupied with hadith as the main basis of their fatwas. Sound hadith must be distinguished from unsound ones. Some were falsely attributed to sahaba and tabi'un but cannot be traced back to them when the isnad is investigated. Special consideration with regard to hadith must be given to Jewish material (isra 'iliyat), which was sorted and evaluated. Other material that crept in due to theological, philosophical, political, and other considerations, also needed to be re-evaluated. False hadith purposely introduced by the enemies of Islam must be distinguished from sound material.

Salafis are divided into three movements:

- Purists, who reject forms of political or organizational activism that divide the Muslim community and divert attention from the study of Islam and the propagation of Salafism. They see jihad in defensive terms, and accept a jihad only when led by a legal Muslim government. They argue that it is forbidden for Muslims to revolt against a Muslim government, no matter how oppressive or unjust.

- Activists, who agree with the Muslim Brotherhood and similar movements that political activism is the best method for achieving the goal of an Islamic state under sharia.

- Salafi-Jihadists, who advocate violence and terror and actively promote rebellion against the state and all perceived enemies of Islam. This third movement is the primary source of Islamist terrorism around the world. It emerged during the antiSoviet jihad in Afghanistan when jihadi, Wahhabi, Deobandi, and other groups cooperated and intermingled in their fight against the common enemy. It was strengthened during the 1991 Gulf War, when the more radical Saudi Salafis rejected reliance on U.S. troops in the Arabian Peninsula to protect Saudi Arabia from Iraqi aggression. ${ }^{54}$

54 Juan Jose Escobar Stemmann, “Middle East Salafism’s Influence and the Radicalization of Muslim Communities in Europe,” Middle East Review of International Affairs 10:3 (September 2006). 


\section{Progressives}

Progressives want to reform Islam by Westernizing it. They accept the separation of religion and state. They reinterpret the Koran and hadith according to secular and liberal Western concepts of human rights, multiculturalism, and feminism. They are also willing to use Western academic tools of textual criticism to examine the Muslim scriptures. Modernists were influential in the 1920s and 1930s and in the early days of independence in the various Muslim states. However, their freedom of expression is now firmly restricted in most Muslim states, where they are currently under tremendous pressure from Islamists and traditionalists. They face charges of apostasy and blasphemy, as well as threats of violence and death. As a result, many have emigrated to the West.

Nasr Hamid Abu-Zayd..$^{5}$ On 14 June 1995, the Appeals Court in Cairo, Egypt, ruled that Dr. Nasr Hamid Abu-Zayd, a professor of Islamic and Arabic Studies at Cairo University, was an apostate from Islam, and ordered his separation from his wife, Dr. Ibtihal Yunis, an assistant professor of French at Cairo University. Following death threats, Professor Abu-Zayd fled Egypt with his wife, and now lives in exile in Belgium.

Abu-Zayd is a liberal academic who claims to be a devout Muslim. He extended his linguistic research to the study of Islamic source texts of Koran and hadith. According to him, the Koran is the revelation of God's words, but it is also a cultural product and a historical phenomenon, given in a specific time and place. The historical text is subject to human understanding and interpretation. While the text is originally divine, it is also historical, and its interpretation is absolutely human. The Koran and the authentic traditions must be analyzed within the context in which they originated (similar to the Western tradition of historicist criticism). The interpretations of the first Muslim generation and of the generations that followed are not final or absolute. To understand and interpret the text today, we must use socio-historical analysis as well as modern linguistic methodologies.

Abu-Zayd championed allegorical and metaphorical readings of the texts, because they allow the reinterpretation of religious law according to its spirit rather than its letter. He urged that an analysis of the Koranic text in its contextual cultural reality must begin with empirical historical facts. Through the analysis of such facts, a scientific understanding of the Koran can be established. Interpretive diversity is necessary, and imposing uniformity leads to the degeneration of the message. Since the message of Islam is universally valid for all, diversity of interpretation is inevitable. Awareness of the difference between the Koran's fixed original contextual meaning and the changeable significance of that meaning will produce interpretations that can accommodate themselves to changing contexts.

55 Fauzi M. Najjar, "Islamic Fundamentalism and the Intellectuals: The Case of Nasr Hamid Abu Zayd,” British Journal of Middle Eastern Studies 27:2 (November 2000): 177-200; Nasr Hamid Abu Zaid, “The Revival of Anti-Modernist Islamic Discourse,” Nasr Abu Zaid page, at: www.pakistanidefenceforum.com/lofiversion/index.php/t11144.html. 


\section{Conclusion}

Muslims operate within a long and continuous system of interpretation from which they cannot be divorced. Western attempts to reinterpret certain Islamic themes, such as violence, jihad, and terrorism are most likely to fail. Muslims react with hurt pride and scorn at any such attempts. At the most, Western governments and scholars can encourage Muslim scholars who interpret their sources in peaceful, non-violent ways.

However, it is imperative that Westerners and Muslims accept and admit that violence and jihad are part of the Muslim source texts. They cannot be wished away. At best they can be marginalized by a reinterpretation that prioritizes the peaceful parts of the source texts by various means (as do a variety of reformist and progressive scholars and movements within Islam).

Western governments have made the mistake of dealing with Islamist movements as though they are the authentic representatives of Muslim communities and of Islam in general, thus further empowering them. A better strategy would be to marginalize these groups, including the Muslim Brotherhood, Jama'at-i-Islami, Deoband, and the Salafis/Wahhabis, as these are the movements that take the jihad passages of the Koran most seriously. Instead, groups that follow progressive interpretations that would limit the applicability of the violent passages to the early period of Islam, and that prioritize the peaceful ones as being the universal and eternal principles of Islam, should be encouraged and supported until they become the dominant forces in the Muslim world. This might take a long time, as the radical groups still enjoy access to funding from oilrich states and have managed to project themselves as the dominant force in contemporary Islam. Their power must be broken as the progressive forces are empowered, given greater resources, and supported to become a political force with the means to take over the leadership of global Islam as well as each individual Muslim state. 


\section{THE QUARTERLY JOURNAL}

\section{Bibliography}

Abootalebi, Ali R.. "Islam, Islamists, and Democracy." Middle East Review of International Affairs 3 (1999).

al-Qurtubi, Tafsir. Classical Commentary on the Holy Koran, translated by Aisha Bewley. London: Dar al-Taqwa, 2003.

Esposito, John L.. "Contemporary Islam: Reformation or Revolution?" in The Oxford History of Islam." New York: Oxford University Press, 1999.

Haddad, Yvonne Y.. "Sayyid Qutb: Ideologue of Islamic Revival." In Voices of Resurgent Islam. New York: Oxford University Press, 1983.

Haddad, Yvonne Y.. "The Quranic Justification for an Islamic Revolution: The View of Sayyid Qutb." Middle East Journal 37, no. 1 (1983): 17-18.

Lichtenthäler, Gerhard. "Muslim, Mystic and Martyr: The Vision of Mahmud Muhammad Taha and the Republican Brothers in the Sudan: Towards an Islamic Reformation?" Islam et Societes au Sud du Sahara 9 (1995).

Mernissi, Fatima. Islam and Democracy: Fear of the Modern World. New York: Perseus Books Group, 2002.

Najjar, Fauzi M.. "Islamic Fundamentalism and the Intellectuals: The Case of Nasr Hamid Abu Zayd." British Journal of Middle Eastern Studies 27, no. 2 (2000): 177-200.

Qutb, Sayyid. The Islamic Concept and its Characteristic. Indianapolis: American Trust Publication, 1991.

Rippin, Andrew. Muslims: Their Religious Beliefs and Practices. London: Routledge, 1990.

Rizvi, Sayyid Athar Abba. Muslim Revivalist Movements in Northern India in the Sixteenth and Seventeenth Centuries . New Delhi: Agra University Press, 1965.

Rizvi, Sayyid Athar Abba. Shah Wali-Allah and His Times. Canberra: Ma'rifat Publishing House, 1980.

Shariati, Ali. Martyrdom: Arise and Bear Witness, trans. Ali Ghassemy. Tehran: Ministry of Islamic Guidance, 1981.

Shariati, Ali. On the Sociology of Islam. Berkeley, CA: Mizan Press, 1979.

Shariati, Ali. What Is To Be Done: The Enlightened Thinkers and an Islamic Renaissance. Houston: IRIS, 1986. 
Stemmann, Juan Jose Escob. "Middle East Salafism's Influence and the Radicalization of Muslim Communities in Europe." Middle East Review of International Affairs 10, no. 3 (2006).

The Oxford Encyclopedia of the Modern Islamic World. New York: Oxford University Press, 1999. 